\title{
Decision Support System Nutritional Supplement Receipt Determination Method Using Simple Additive Weighting (SAW)
}

\author{
Muhammad Irfan Sipayung1, Arjon Samuel Sitio ${ }^{2}$ \\ ${ }^{1,2}$ Informatics Engineering Study Program, STMIK Pelita Nusantara Jl. Iskandar Muda No. 1. \\ Medan, North Sumatera, Indonesia 20154
}

E-mail:1rfanbro578@gmail.com,arjonsitio@gmail.com

\begin{abstract}
Nutrition is a component of body builders in order to maintain and repair the tissues so that the function of the body can function properly. Currently in the village broke promontory has run a program providing nutrition food additive in which the program is based as a growth pattern in the village communities are uneven due to the lack of ancestry in consuming foods that are healthy and nutritious. Until now there has been the way of effective work to determine the acceptance of additional nutrients in the village broke headland. This study aims to assist the village in determiningNutritional Supplement acceptance in the village of Tanjung Disconnect. This system is built using a simple method that perogram Additvive weighting that can be done more effectively. Additvive simple weighting method is one method used in decision support seistem prosesperhitungnya by finding the weight values for each attribute.
\end{abstract}

Keywords: Decision Support Systems, Simple Additive weighting, Nutrition

\section{Introduction}

Nutrition becomes a benchmark for the level of health of the individual or group of people in life. Currently the village has promontory dropping menjalahkan based program for my growth pattern on the people residing in the village is uneven due to lack of family in a healthy diet and nutritious. Until now there has been the way of effective work to determine the acceptance of additional nutrients in the village broke headland. In this study, the authors use a simple additive weighting method (SAW). With this system will speed up the village can choose beneficiary data that are relevant in determining the approach used in the decision making process to evaluate the activities of alternative election for the determination of additional nutrients to masayakat pemberiaan.

\section{Theory}

\section{A. Decision Support System}

According to Turban and Aronson (2011: 75) Decision Support System (DSS) or Decision Support System (DSS) is a system that is intended to support decision-makers managerial decision situations semistructured and structured SPK can be applied in the process of providing solutions in the decision to a problem in conditions of many criteria or Multiple criteria Decision Making (MCDM) in the SPK. The solution provided is shown is a suggestion in the form of ratings.

\section{B. Openness component Decision Support}

As for the components of Decision Support Systems are as follows:

a) Data Management, includes a database containing relevant data and governed by a system called Database Management System (DBMS).

b) Management Model, a software package that includes financial models, statistics, management science, or other quantitative models that provide analytical skills and management system related software.

c) The user interface, media interaction between the system with the user, so that users can communicate and give commands on the CMS through this subsystem.

d) Knowledge-based subsystems, subsystems can support other subsystems or act as a stand-alone component. In order to more clearly understand the conceptual model SPK. (Nofriansyah and defit, 2017: 3)

\section{Additive weighting system}

Simple Additive weighting can be interpreted as a simple weighting method or weighted summation on solving problems in a decision support system. The concept of this method is to look at the priority scale performance ratings of each alternative called attributes (Nofriansyah, 2017: 33). In this study, the authors use 
Simple Additive weighting method (SAW) The steps are as follows:

a) Specifies an alternative, yaituAi.

b) Menentukankriteriayangakan referenced dalampengambilan decision, yaituCj.

c) Memberikannilai ratingkecocokan each alternative padasetiap criteria.

d) Determining the weight of preference or importance level (W) of each criterion. $\mathrm{W}=[\mathrm{W} 1 \mathrm{~W} 2 \mathrm{~W} 3 \ldots \mathrm{WJ}]$

e) Creating tables ratingkecocokan of setiapalternatif padasetiap criteria.

f) Membuatmatrikkeputusanyangdibentukdaritableratingkecocokandarisetiap alternatifpadasetiapkriteria value of each alternative (Ai) on each criterion $(\mathrm{Cj})$ is already determined, where $\mathrm{i}=1,2 \mathrm{~m}$ and $\mathrm{j}=1,2, . . \mathrm{n}$

$$
\mathrm{X}=\begin{array}{ccc}
\mathrm{r} 11 & r 12 \otimes & \text { rij } \\
r i 1 & \text { ri2 } \otimes & \text { rij }
\end{array}
$$

g) Melakukannormalisasimatrikkeputusan dengancaramenghitungnilai ratingkinerjaternomalisasi (rij) of alternatifAipadakriteriaCj.

Formula for normalization are: normalization calculation is based on the costs and benefits.

Rij $\left\{\begin{array}{l}\frac{\mathrm{Xij} \text { if } \mathrm{j}}{\operatorname{Max_{\mathrm {i}}\mathrm {Xij}}} \text { is an attribute of the advantages (benefits) } \\ \text { Mini Xij if j is an attribute of the cost (cost) }\end{array}\right.$

$$
\mathrm{Xij}
$$

Where :
a) $\mathrm{Vi}$
$=$ Ranking for each alternative
b) $\mathrm{Rij}$
$=$ Normalized performance rating
c) Max xij
= Maximum value of each row and column
d) Min xij
$=$ Minimum value of each row and column
e) $\mathrm{Xij}$
$=$ Rows and columns of a matrix
f) Benefit
$=\mathrm{jka}$ greatest value is best
g) $\operatorname{cost}$
$=$ if the smallest is the best value

Vi larger value indicates that the alternative Ai is selected were:

a) It said the criteria of profit if the value of benefit decision-making, otherwise if the cost criterion raises the cost for decision making.

b) If such criteria profits then divided by the mean value of each column, while the cost criteria of each column divided by the value.

c) Results of ratingkinerja ternomalisasi value (rij) form a normalized matrix (R)

$$
\mathrm{R}=\begin{array}{ccc}
r 11 & r 12 \otimes & r i j \\
\nabla & \ldots & \otimes \\
r i 1 & r i 2 \otimes & r i j
\end{array}
$$

d) Hasilakhirnilaipreferensi (Vi) diperolehdaripenjumlahandariperkalianelemenbaris normalized matrix (R) denganbobotpreferensi (W) yangbersesuaianelemankolom matrix (W). niali preference for each alternative (Vi) is given as:

$\mathrm{Vi}={ }_{j=1}^{n} W j R i j$

Preference value for each alternative is obtained by multiplying the result menjumlahan normalized

performance rating with weighting each criterion.

Where :

a) $\mathrm{Vi}=$ The final value of alternati

b) $\quad$ wj $=$ The weights have been determined

c) $\quad$ Rij $=$ Normalization matrix

The calculation result $\mathrm{Vi}$ greater value identifies that the alternative $\mathrm{Ai}$ is the best alternative.

\section{Understanding Nutrition}

Nutrition is defined as the process of using food consumed organisms normally through the process of digestion, absorption, transport, storage, metabolism and expenditure of nutrients to sustain life, growth and normal functioning of the body organs as well as to generate power (irianto, 2006: 2). 
In the medical world of nutrition as a component of the human body builder so that it can maintain and repair the tissues of the human body functions itself. The -macam kinds of substances included in nutrition is water, carbohydrates, minerals, vitamins, proteins, lipids or fats.

\section{Results and Discussion}

\section{A. Problem analysis}

Analysis is an activity that starts from the beginning in the study and evaluate a form of the problems found. The system to be constructed can not be separated from the data recipients to take advantage of additional nutrients and Simple Additive Weigthing (SAW) in the decision-making process. Based on the results of research carried out in the village of Tanjung Break up with potential recipients then use data analysis was conducted on the document input, process analysis, and document output. In the system making the village the candidate receiving the data needed nutritional supplements as a reference to describe the system requirements.

\section{B. Discussion}

1) Implementation Methods

a. Determining Alternative

An alternative is the recipient of a qualified determination of additional recipients of nutrition in rural communities Tanjung Disconnect.

b. Determining each each criterion

Table 1.

Data criteria

\begin{tabular}{ccc}
\hline Criteria & sub Criteria & Information \\
\hline C1 & Nutritional status of family & $\mathrm{L}$ \\
C2 & Income & $\mathrm{L}$ \\
C3 & The number of dependents & $\mathrm{L}$ \\
$\mathrm{C} 4$ & Age & $\mathrm{L}$ \\
$\mathrm{C} 5$ & Disease & $\mathrm{L}$ \\
\hline
\end{tabular}

Table 2.

weighted criteria

\begin{tabular}{|c|c|c|}
\hline Criteria & variables & Information \\
\hline 1 & Very important & $1: 00$ \\
\hline 2 & Urgent & 0.80 \\
\hline 3 & Enough & 0.60 \\
\hline 4 & Low & $0: 40$ \\
\hline 5 & Very low & $0: 20$ \\
\hline
\end{tabular}

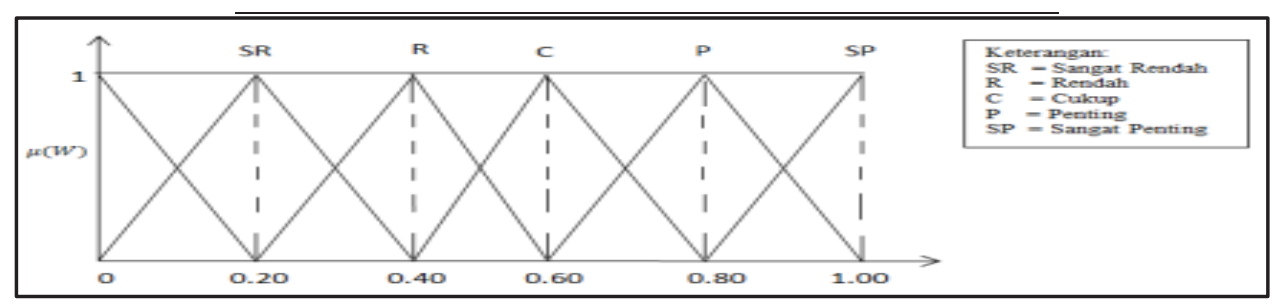

Picture 1. Weight chart

c. Rating determine the suitability

- Nutritional status of family

Table 3.

The weight of the nutritional status criteria

\begin{tabular}{lll}
\hline Benefit & \\
\hline Family Nutritional & variables & Weight \\
Status & Low & $0: 40$ \\
\hline Well & Very important & $1: 00$ \\
\hline
\end{tabular}

- criteria Revenue 
Table 4.

Income criteria weights

\begin{tabular}{lll}
\hline \multicolumn{1}{c}{ cost } & & \\
\hline $0 X \leq$ Rp. 500,000 & variables & Weight \\
$\leq x \leq 500,000$ Rp.1.000.000 & Very important & $1: 00$ \\
$\leq x \leq$ Rp 1,000,000. 2,000,000 & Urgent & 0.80 \\
Rp. 2,000,000 & Enough & 0.60 \\
\hline
\end{tabular}

- Criteria Number of Dependents

Table 5.

Weighting criteria Number of dependents

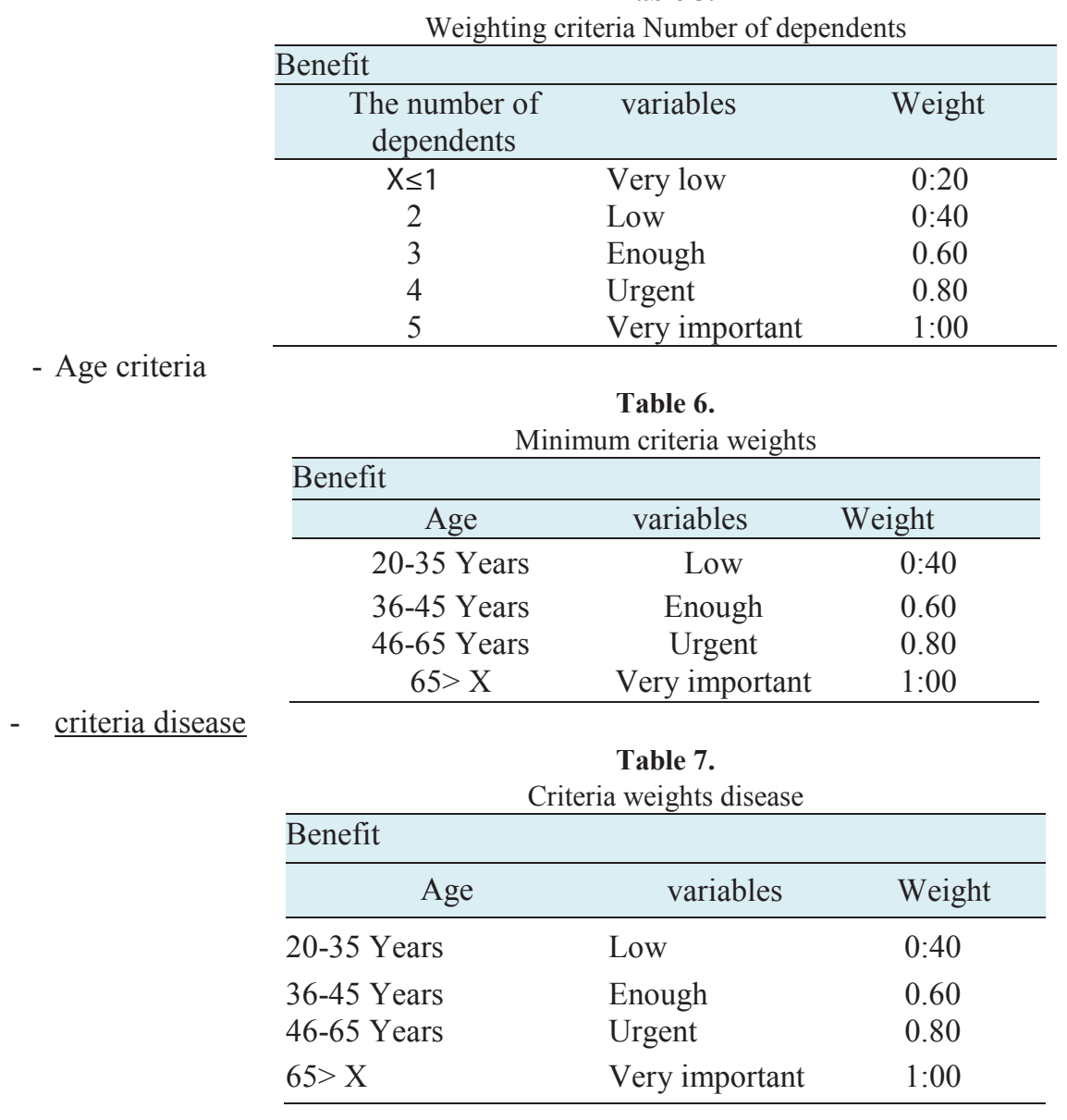

- Weights determine preferences or kepentigan level (W), each criterion

Table. 8

Variable Interests Weights

\begin{tabular}{lllc}
\hline No. & \multicolumn{1}{c}{ variable } & name Interests & $\begin{array}{c}\text { Weigh } \\
\text { t }\end{array}$ \\
\hline 1 & Family Nutritional & Very important & $0: 30$ \\
& Status & Very important & $0: 30$ \\
2 & Income & Very important & $0: 20$ \\
3 & The number of & Urgent & $0: 10$ \\
4 & dependents & Urgent & $0: 10$ \\
5 & Disease & & \\
\hline
\end{tabular}

Recipient data is important data in decision support system determination nutrition reception SAW method. 
Journal of Computer Networks, Architecture and High Performance Computing e-ISSN 2655-9102, Volume 2, No. 1, January 2019, pp 30-37

\begin{tabular}{clcl}
\hline NO & \multicolumn{1}{c}{ Name } & L / P & Occupation \\
\hline 1 & Khamarudin & L & BHL \\
2 & Widodo & L & employee \\
3 & Saidi & L & employee \\
4 & Boimen & L & employee \\
5 & supriadi & L & employee \\
\hline
\end{tabular}

d. Creating a table rating the suitability of each alternative on each criterion.

Here is sampled five recipients recipient data nutrition, which will be tested based on predetermined criteria.

table 10

Data from the prospective recipient criteria for nutrition

\begin{tabular}{llllll}
\hline Alternative & \multicolumn{1}{c}{$\begin{array}{c}\text { Family } \\
\text { Sutritional } \\
\text { Status }\end{array}$} & Data Collection & $\begin{array}{c}\text { The number } \\
\text { of dependents }\end{array}$ & Age & Disease \\
\hline A1 & Bad & Rp. 800.000 & 4 & 29 & there is \\
A2 & Bad & Rp. 1. 000.000 & 2 & 35 & there is \\
A3 & Well & Rp. 1. 300.000 & 3 & 40 & there is \\
A4 & Bad & Rp. 500,000 & 4 & 39 & there is \\
A5 & Well & Rp. 2. 500,000 & 5 & 45 & $\begin{array}{l}\text { There is } \\
\text { no }\end{array}$ \\
\hline
\end{tabular}

Table 11.

Match Rating From Any Alternative On Any Criteria

\begin{tabular}{cccccc}
\hline \multirow{2}{*}{ Alternative } & \multicolumn{5}{c}{ weights Criteria } \\
& C1 & C2 & C3 & C4 & C5 \\
\hline A1 & $1: 00$ & 0.80 & 0.80 & $0: 40$ & $0: 40$ \\
A2 & $1: 00$ & 0.80 & $0: 40$ & $0: 40$ & $0: 40$ \\
A3 & $0: 40$ & 0.60 & 0.60 & 0.60 & $0: 40$ \\
A4 & $1: 00$ & $1: 00$ & 0.80 & 0.60 & $0: 40$ \\
A5 & $0: 40$ & $0: 40$ & $1: 00$ & 0.60 & $0: 20$ \\
\hline
\end{tabular}

e. The decision matrix formed from a decision matrix table rating the suitability of any alternatifpada each criterion

\section{f. Doing Normalization Matrix}

$$
\begin{array}{lllll}
1.00 & 0.80 & 0.80 & 0.40 & 0.40 \\
1.00 & 0.80 & 0.40 & 0.40 & 0.40 \\
0.40 & 0.60 & 0.60 & 0.60 & 0.40 \\
1.00 & 1.00 & 0.80 & 0.60 & 0.40 \\
0.40 & 0.40 & 1.00 & 0.60 & 0.20
\end{array}
$$

The next step is Perform normalization matrix to calculate the value normalized performance rating (rij) of the alternative $\mathrm{Ai}$ Reviewed by $\mathrm{Cj}$ attribute equations adjusted for the type attribute.

Formula for normalization are as follows

$\operatorname{rij}\left\{\begin{array}{l}\frac{\mathrm{Xij} \text { if } \mathrm{j} \text { is an attribute }}{\operatorname{Max}_{\mathrm{i}} \mathrm{Xij}} \text { advantage (benefit) } \\ \text { Mini Xij if } \mathrm{j} \text { is an attribute of the cost (cost) } \\ \mathrm{Xij}\end{array}\right.$

- Values Family Nutritional Status

$$
\begin{aligned}
& r_{11}=\frac{1.00}{\max (1.00 ; 1.00 ; 0.40 ; 1.00 ; 0.40)}=\frac{1.00}{1.00}=1 \\
& r_{21}=\frac{1.00}{\max (1.00 ; 1.00 ; 0.40 ; 1.00 ; 0.40)}=\frac{1.00}{1.00}=1
\end{aligned}
$$




$$
\begin{gathered}
r_{31}=\frac{0.40}{\max (1.00 ; 1.00 ; 0.40 ; 1.00 ; 0.40)}=\frac{0.40}{1.00} \\
r_{41}=\frac{1.40}{\max (1.00 ; 1.00 ; 0.40 ; 1.00 ; 0.40)}=\frac{1.00}{1.00}=1 \\
r_{51}=\frac{0.40}{\max (1.00 ; 1.00 ; 0.40 ; 1.00 ; 0.40)}=\frac{0.40}{1.00}=0.4 \\
-\quad \text { Income } \\
r_{12}=\frac{\min 0.80 ; 0.80 ; 0.60 ; 1.00 ; 0.40}{0.80}=\frac{0.40}{0.80}=0.5 \\
r_{22}=\frac{\min 0.80 ; 0.80 ; 0.60 ; 1.00 ; 0.40}{0.80}=\frac{0.40}{0.80}=0.5 \\
r_{32}=\frac{\min 0.80 ; 0.80 ; 0.60 ; 1.00 ; 0.40}{0.60}=\frac{0.40}{0.60}=0.67 \\
r_{42}=\frac{\min 0.80 ; 0.80 ; 0.60 ; 1.00 ; 0.40}{1.00}=\frac{0.40}{1.00}=0.4 \\
r_{52}=\frac{\min (0.80 ; 0.80 ; 0.60 ; 1.00 ; 0.40)}{0.40}=\frac{0.40}{0.40}=1
\end{gathered}
$$

- Value Number of Dependents

$$
\begin{aligned}
& r_{13}=\frac{0.80}{\max (0.80 ; 0.40 ; 0.60 ; 0.80 ; 1.00)} \\
& =\frac{0.80}{1.00}=0.8 \\
& r_{23}=\frac{\max (0.80 ; 0.40 ; 0.60 ; 0.80 ; 1.00)}{20.40} \\
& =\frac{0.40}{1.00}=0.4 \\
& r_{33}=\frac{0.60}{\max 0.80 ; 0.40 ; 0.60 ; 0.80 ; 1.00} \\
& =\frac{0.60}{1.00}=0.6 \\
& r_{43}=\frac{0.80}{\max 0.80 ; 0.40 ; 0.60 ; 0.80 ; 1.00} \\
& =\frac{0.80}{1.00}=0.8 \\
& r_{53}=\frac{1.00}{\max (0.80 ; 0.40 ; 0.60 ; 0.80 ; 1.00)} \\
& =\frac{1.00}{1.00}=1
\end{aligned}
$$

- value Age

$$
\begin{gathered}
r_{14}=\frac{0.40}{\max (0.40 ; 0.40 ; 0.60 ; 0.60 ; 0.60)}=\frac{0.40}{0.60} \\
=0.67 \\
r_{24}=\frac{0.40}{\max (0.40 ; 0.40 ; 0.60 ; 0.60 ; 0.60)}=\frac{0.40}{0.60} \\
r_{34}=\frac{0.67}{\max (0.40 ; 0.40 ; 0.60 ; 0.60 ; 0.60)}=\frac{0.60}{0.60} \\
=1
\end{gathered}
$$




$$
\begin{gathered}
r_{44}=\frac{0.60}{\max (0.40 ; 0.40 ; 0.60 ; 0.60 ; 0.60)}=\frac{0.60}{0.60} \\
=1 \\
r_{54}=\frac{0.60}{\max (0.40 ; 0.40 ; 0.60 ; 0.60 ; 0.60)} \\
=\frac{0.60}{0.60}=1
\end{gathered}
$$

- Disease

$$
\begin{aligned}
& r_{15}=\frac{0.40}{\max (0.40 ; 0.40 ; 0.40 ; 0.40 ; 0.20)}=\frac{0.40}{0.40}=1 \\
& r_{25}=\frac{0.40}{\max (0.40 ; 0.40 ; 0.40 ; 0.40 ; 0.20)}=\frac{0.40}{0.40}=1 \\
& r_{35}=\frac{0.40}{\max (0.40 ; 0.40 ; 0.40 ; 0.40 ; 0.20)}=\frac{0.40}{0.40}=1 \\
& r_{45}=\frac{0.40}{\max (0.40 ; 0.40 ; 0.40 ; 0.40 ; 0.20)}=\frac{0.40}{0.40}=1 \\
& r_{55}=\frac{0.20}{\max (0.40 ; 0.40 ; 0.40 ; 0.40 ; 0.20)}=\frac{0.20}{0.40} \\
& =0.5 \\
& \begin{array}{lllll}
1.00 & 0.50 & 0.80 & 0.67 & 1.00
\end{array} \\
& \begin{array}{lllll}
1.00 & 0.50 & 0.40 & 0.67 & 1.00
\end{array} \\
& \mathrm{R}=\begin{array}{lllll}
0.40 & 0.67 & 0.60 & 1.00 & 1.00
\end{array} \\
& \begin{array}{llllll}
1.00 & 0.40 & 0.80 & 1.00 & 1.00
\end{array} \\
& \begin{array}{lllll}
0.40 & 1.00 & 1.00 & 1.00 & 0.50
\end{array}
\end{aligned}
$$

g. Determining the value of preferences (Vi) obtained from the sum of the normalized rows of the matrix multiplication element $(\mathrm{R})$ with a preference weighting $(\mathrm{W})$ corresponding eleman column matrix $(\mathrm{W})$. formula:

$$
\mathrm{Vi}={ }_{j=1}^{n} W j R i j
$$

Ranking process using weights given by decision makers:

$$
\begin{aligned}
\mathrm{W}= & {[0.3 ; 0.3 ; 0.2 ; 0.1 ; 0.1] } \\
V_{1}= & 0.30 \times 1.00+0.30 \times 0.50+0.20 \times 0.80+0.10 \times 0.67+0.10 \times 1.00 \\
& =0.3+0.15+0.16+0,067+0.1 \\
& =0.77 \\
V_{2}= & 0.30 \times 1.00+0.30 \times 0.50+0.20 \times 0.40+0.10 \times 0.67+0.10 \times 1.00 \\
= & 0.3+0.15+0.08+0,067+0.1 \\
& =0.7 \\
V_{3}= & 0.30 \times 0.40+0.30 \times 0.67+0.20 \times 0.60+0.10 \times 1.00+0.10 \times 1.00 \\
= & 0.12+0,201+0.12+0.1+0.1 \\
= & 0.64 \\
V_{4}= & 0.30 \times 1.00+0.30 \times 0.40+0.20 \times 0.80+0.10 \times 1.00+0.10 \times 1.00 \\
= & 0.3+0.12+0.16+0.1+0.1 \\
= & 0.78 \\
V_{5}= & 0.30 \times 0.40+0.30 \times 1.00+0.20 \times 1.00+0.10 \times 1.00+0.10 \times 0.50 \\
= & 0.12+0.3+0.2+0.1+0.05 \\
= & 0.77
\end{aligned}
$$

Below is a table ranking the preferences based on the weights of each alternative. The reference in this perangkingan is based on the highest value (max) which made the highest rank. 
Table 12

Rangking Results

\begin{tabular}{|c|c|c|}
\hline Rank & Alternative & $\begin{array}{c}\text { Weight Value Prefernsi } \\
\text { (Vi) }\end{array}$ \\
\hline 1. & Boimin or A4 & 0.78 \\
\hline 2. & Khamarudin or A1 & 0.77 \\
\hline 3. & Supriadi or A5 & 0.77 \\
\hline 4. & Widodo or A2 & 0.69 \\
\hline 5. & Saidi or A3 & 0.64 \\
\hline
\end{tabular}

\section{Conclusion}

Based on the development that has been done during the process of analysis and design to implementation of decision support system of determining an additional receiver nutrition with Simple Additive weighting method it can be concluded as follows:

1. Decision support systems determine additional recipients and testing of nutritional computerized decision support systems result determination nutritional supplement recipients have used the Simple Additive weighting method.

2. With the implementation of decision support systems with Simple Additive weighting method can be used for the determination of nutrients by inserting an additional receiver in the form of alternative data then enter the weight value is seen on the criteria, so as to generate value calculation and perengkingan recipients name candidates. With the decision support systems with Simple Additive weighting calculation method that can help the country in completing their duties effectively and efficiently.

\section{Reference}

[1] DickyNofriansyah, SarjonDefit, 2017. Multi Criteria Decision Making (MCDM) PadaSistem Pendukung Keputusan.Yogyakarta: Deepublish Publisher.

[2] Kusrini . "Konsep Dan Aplikasi Sistem Pendukung Keputusa". Yogyakarta: AndiOffest.

[3] Jubilee Enterprise, 2018. HTML, PHP, dan MySQL untukPemula, Jakarta: Gramedia.

[4] Ibnul jazari, at https://informasi-anakutm.blogspot.com/2016/06/cara-perhitungan-dan-contoh-kasus.html

[5] Roi Marsita Simanjuntak, "SistemPendukungKeputusaRemberian Pinjaman Terhadap Nasabah Dengan Metode Simple Aditive Weigghting (SAW)", Informasi dan Teknologi Ilmiah, 2015, ISSN:2339-210X..

[6] Aning Setya Rini, Dewi Soyusiawaty, "SistemPendukungKeputusanSeleksi Penerimaan Beras Untuk Keluarga Miskin Dengan Metode Simple Addditive Weighting", Jurnal Sarjana Informatika, e-ISSN:2338-5197, Volume 2 Nomor 2, Juni 2014.

[7] Roi Marsitta Simanjuntak, Tonni Limbong." Sistem Pendukung Keputusan Pemberian Pinjaman Kepada Nasabah Dengan Metode Simple Addtive Weighting (Saw) Studi Kasus : PT.BPR Lasamana Guna Percut", Informasi dan Teknologi ilmiah (INTI), Vol. 5 . No. 2. Januari 2015.

[8] Teuku Mufizar, Rima listiani lestari. " Implementasi Metode Simple Additive Weighting (SAW) Pada Sistrm Pendukung Keputusan Pemebrian Kelayakan Kredit Pinjaman Komersial SB Simpan Pinjam Tasikmalaya", CSRID Jounal, Vol. 6. No. 2, hal. 96-107. Juni 2014.

[9] Apriansyah Putra, Dinna Yunika Hardiyanti, "Penentuan Penerima Beasiswa Menggunakan Fuzzzy MADMM", Seminar nasional informatika 2011, ISSN: 1979-2328.

[10] Ayu Kartika Puspa, Reni Nursyanti." Sistem Pendukung Keputusan Penyakit Gizi buruk Menggunakan MetodeSimple Addiitive Weighting $(S A W)^{\prime \prime}$. Expert - jurnal Managgement Sistem Informasi dan Teknologi. Hal 46-55. 